\title{
Comparison of Digital Elevation Models for the designing water reservoirs: a case study Pskom water reservoir.
}

\author{
Khojiakbar Khasanov ${ }^{*}$, and Azamat Ahmedov \\ Tashkent Institute of Irrigation and Agricultural Mechanization Engineers, Tashkent, Uzbekistan
}

\begin{abstract}
This study investigates the accuracy of various DEMs (SRTM DEM, ASTER GDEM, and ALOS PALSAR DEM) for the area of the designing Pskom water reservoir (recommended to construction in Pskom River, in Tashkent region. DEMs are compared for the study area using the Global Mapper application and selection Ground Control Points (GCP). The RMSE we calculate is the most easily interpreted statistic as the square root of the mean square error because it has the same units as the quantity drawn on the vertical axis. Results show that SRTM based measurements of ground control points (GCPs) exhibit RMSE of $15.72 \mathrm{~m}$ while ASTER DEM based measurements exhibits and RMSE of $18.47 \mathrm{~m}$, ALOS PALSAR exhibit RMSE of $14.02 \mathrm{~m}$ for the Water reservoir located in the plain. There are AOS PALSAR outperforms SRTM and ASTER DEM in detecting vertical accuracy. Based on the capabilities of the Global Mapper program, we can build the longitudinal profile of the approximate location where the dam can be built in each DEM and compare. The results obtained show that the dam height is $187 \mathrm{~m}$ at ALOS PALSAR DEM, 168 $\mathrm{m}$ at ASTER GDEM, and $175 \mathrm{~m}$ at SRTM. The study found that using ALOS PALSAR data in the design of the proposed Pskom Reservoir for construction leads to a more accurate result. Comparing the DEMs data shows that there is more difference between the vertical accuracy; the horizontal accuracy level is almost the same. The results were obtained using ALOS PALSAR data in determining the storage volume $\left(\mathrm{W}=479368568 \mathrm{~m}^{3}\right)$ and area $(\mathrm{F}=8.31 \mathrm{sq} ., \mathrm{km})$ of the water reservoir.
\end{abstract}

\section{Introduction}

Reservoirs - created by damming rivers throughout their history have played an important role in societies around the world, regulating floods, generating hydroelectricity, and redistributing river runoff for irrigation, usually where natural precipitation is volatile or seasonal as they store water during wet periods to make it available during dry periods[13].

Uzbekistan is a mostly arid region, where evaporation exceeds precipitation and annual precipitation is lower. Its climate is mostly arid, and its water resources are unevenly distributed both in space and time. This means that agricultural production is impossible

* Corresponding author: kh.khasanov@mail.ru 
without irrigation. So, the irrigation system is primarily one of the main economic development factors, employment, and food security in Uzbekistan. There are 59 reservoirs in Uzbekistan, 29 of which are located in the floodplains of rivers and are a channel, and 30 are bulk reservoirs[4-6].

An acute shortage of water resources in the region will demand the construction of new and reconstruction of the operated water storage facilities. Nowadays, Uzbekistan pays great attention to the construction of reservoirs for irrigation and energy purposes. Identification of potential sites for constructing reservoirs and obtaining initial data (the geographical location, storage volume, water surface area, profile of the dam site, and others) imposes a great task on project institutes.

In the water reservoir design, methods such as field surveying or using topographic maps can yield high accuracy terrain data, but they are time-consuming and labor-intensive. Today, geographic information system (GIS) and Remote Sensing (RS) technologies are an integral part of many branches of industry. Using the digital elevation model (DEM) in the GIS, it is possible to determine the potential location for the reservoir construction, to estimate the volume of the reservoir build-up, to simulate groundwater, to determine possible erosion and the mudflow hazard and mudflow-resistant areas[7, 8]. The introduction of GIS and RS technologies into human life has made it possible to accomplish many tasks quickly, cheaply, and accurately, including in the performance of environmental engineering work [1], [9-12].

\subsection{Digital Elevation Model}

The application of remote sensing methods to extract DEM from satellite images instead of direct measurement techniques has become a trend. DEM is the digital image of Earth elevation concerning any coordinate system, the simplest form and digital characteristics of the topographical surface; it can be used in determining detentions and uplands at any point of earth, creating 3D models of the earth surface, obtaining hydrological and geological analysis, surveying natural resources, managing agriculture[13-15]. Nowadays, remote sensing satellites, in addition, to their high temporal and spatial resolutions, low-cost production compared to direct measurements. DEMs produced from these sources vary in cost, accuracy, availability, and sampling density[16].

\subsection{Shuttle Radar Topography Mission (SRTM)}

SRTM - The first disposable SAR (synthetic aperture radar) interferometer in space was launched after a short delay aboard the Space Shuttle Endeavor (STS-99). On February 11, 2000, two modified antenna synthetic aperture radar systems were operated. It was a joint project of the U.S. Department of Defense's National Aerospace and Space Administration, the National Geographic Intelligence Agency. Equipped with a set of SRTM C-band and XBand synthetic aperture radars, it allows developing a consistent and accurate global digital ground model and topographic maps of all land surfaces from $+60^{\circ}$ to $-56^{\circ}$ latitude, and this has been successful achieved. SRTM DEM data has a horizontal resolution of 1 arc per second and a vertical resolution of $10 \mathrm{~m}$. The level and resolution of data processing will be three types across the SRTM Data Products: The first, Version 1 (2003-2004), is almost the raw data, processed from raw C-band radar signals spaced at intervals of 1 arc-second nonvoid filled elevation data. The second, Version 2.1 ( 2005), is an edited version of v1; Void Filled elevation data result from additional processing to address areas of missing data or voids in the SRTM Non-Void Filled collection. The third, Version 3 (2013), also known as SRTM Plus, 1 Arc-Second Global elevation data offer worldwide coverage of void-filled data at a resolution of 1 arc-second (30 meters)[17]-[23]. 


\subsection{Advanced Spaceborne Thermal Emission Reflectometer(ASTER)}

ASTER - the freely available Advanced Spaceborne Thermal Emission and Reflection Radiometer Global Digital Elevation Model Version 2 (ASTER GDEM) is a joint initiative undertaken by the Ministry of Economics, Trade, and Industry (METI) of Japan and the National Aeronautical and Space Administration (NASA) of the United States, was released to the public in mid-October, 2011. The first ASTER GDEM was released in 2009, with Version 2 being released in 2011. The ASTER GDEM Version 3 maintains the GeoTIFF format and the same gridding and tile structure as in previous versions, with 30meter spatial resolution and $1^{\circ} \times 1^{\circ}$ tiles. ASTER thermal bands measure not just surface temperature but also surface emissivity spectra, and the measurements are subject to atmospheric effects. G-DEM is expected to be a better source of global topographic information for various scientific applications[24]-[27].

\subsection{Advanced Land Observation System}

The Advanced Land Observing Satellite (ALOS) was launched on January 24, 2006, by the Japan Aerospace and Exploration Agency (JAXA) and was operational until May 12, 2011. ALOS, also referred to as DAICHI, (the Japanese often give two names to each of their space projects; the names are used interchangeably in the JAXA literature), captured 6.5 million scenes during its five years of operation. ALOS is equipped with three Earth observation sensor instruments: the Panchromatic Remote-sensing Instrument Stereo Mapping (PRISM) to measure precise land elevation, the Advanced Visible and Near Infrared Radiometer type 2 (AVNIR-2) to observe what covers land surfaces, and the Phased Array type L-band Synthetic Aperture Radar (PALSAR) to enable day-and-night and all-weather land observations. ALOS is thus expected to show high-resolution capability inland observations. The ALOS satellite was successfully launched from the Tanegashima Space Center on January 24, 2006 (Japan Standard Time) using an H-IIA launch vehicle [8], [28-33].

Considering that the total data produced by the ALOS sensors daily (around 700 Gbyte) was beyond the capabilities of any single agency to attempt to manage, but that there was worldwide interest in the use of ALOS data, JAXA has established the concept of the ALOS Data Nodes with local archives, as a mechanism for sharing the processing and distribution load.

\subsection{Data Accuracy}

Accuracy is an important characteristic of DEM and depends on various factors: the interpolation methods of data, the density of data, data quality and topographic features of the surface and/or technical reasons: improper instrument operation, physical limitations of sensors[34], [35]. Moreover, these factors can cause adverse effects for some DEM-based positioning errors for applications due to the altitude data acquisition methodology and the different processing stages of the models. DEMs are prone to errors because they can never be completely eradicated, and they need to be managed effectively and investigate their errors[14, 16], [36-41].

This study investigates the accuracy of various DEMs (SRTM DEM, ASTER GDEM, and ALOS PALSAR DEM) for the area of the designing Pskom water reservoir (recommended to construction in Pskom River, in Tashkent region, 'figure 1'.). DEMs are compared for the study area using the Global Mapper application and selection Ground Control Points (GCP). 


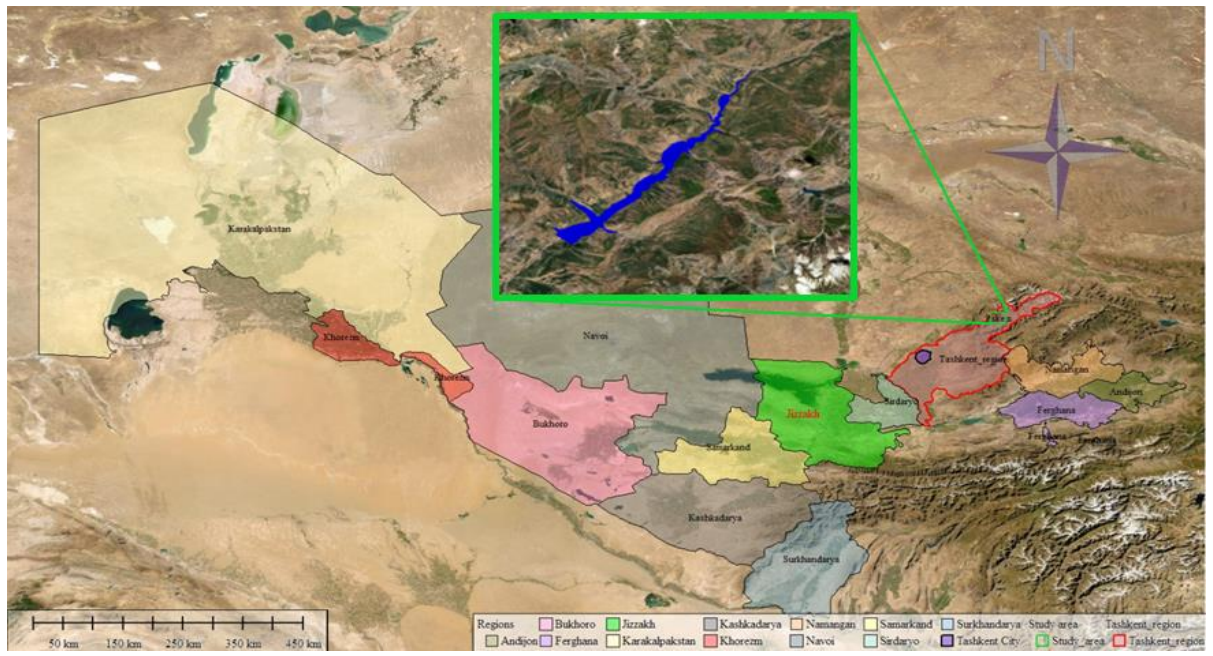

Fig. 1. Study area. Pskom water reservoir is recommended for construction in Pskom River. (Tashkent region, Uzbekistan)

\section{Material and Methods}

The overall purpose of this paper is to compare the accuracy of SRTM DEM, ASTER DEM ALOS PALSAR data downloaded by free open-search websites for the area of the designing Pskom water reservoir. And to determine the water storage volume and area of the reservoir based on high-precision DEM data for that region. The vertical accuracy of each DEM elevation matrix is estimated using data from the Global Positioning System (GPS) at 40 control points obtained from intensive geodetic surveys. These points cover almost the entire area 'figure 2 '.
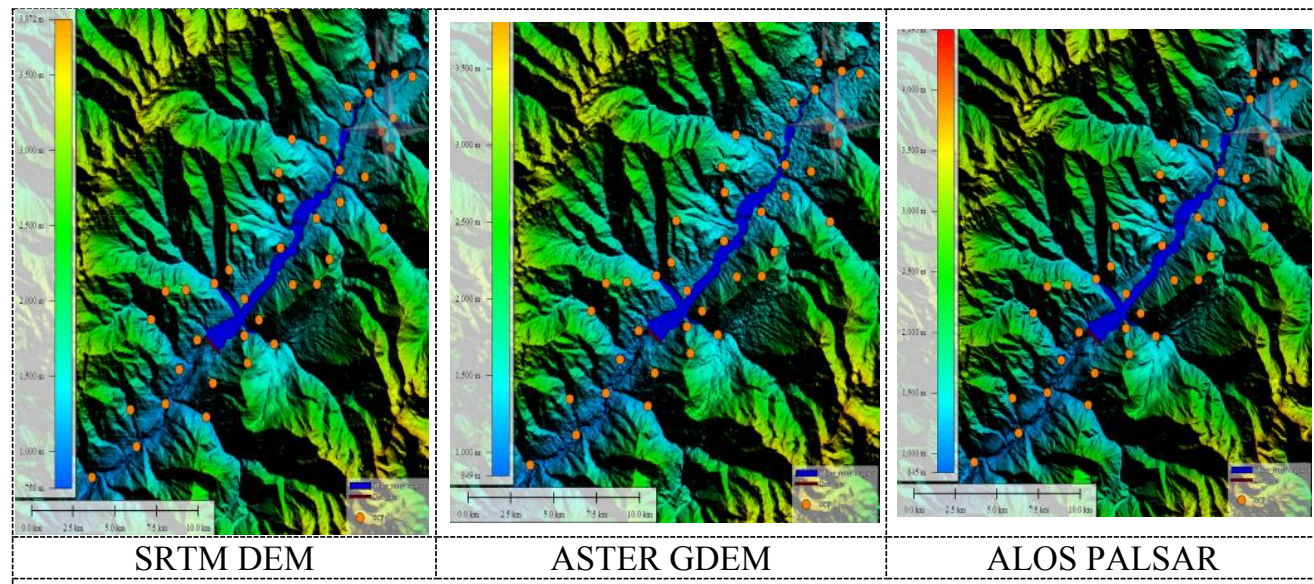

Fig. 2. DEM dates of study area and control points 
Table 1. Metadata

\begin{tabular}{|c|c|}
\hline SRTM DEM & ASTER DEM \\
\hline FILENAME $=$ SRTM DEM & FILENAME $=$ ASTER DEM \\
\hline PROJ_DESC=UTM Zone 42 / WGS 84 / meters & PROJ_DESC $=$ UTM Zone 42 / WGS84 / meters \\
\hline COVERED AREA $=158.74 \mathrm{sq} \mathrm{km}$ & COVERED AREA=158.74 sq km \\
\hline NUM COLUMNS=316 & LOAD TIME $=0.02 \mathrm{~s}$ \\
\hline NUM ROWS=346 & NUM COLUMNS=316 \\
\hline NUM BANDS $=1$ & NUM ROWS=346 \\
\hline PIXEL WIDTH=38.219 meters & NUM BANDS=1 \\
\hline PIXEL HEIGHT $=38.219$ meters & PIXEL WIDTH=38.219 meters \\
\hline MIN ELEVATION=985.1 m & PIXEL HEIGHT $=38.219$ meters \\
\hline MAX ELEVATION=1219.1 m & MIN ELEVATION=986.5 m \\
\hline ELEVATION UNITS=METERS & MAX ELEVATION=1232.2 m \\
\hline BIT DEPTH $=32$ & ELEVATION UNITS=METERS \\
\hline SAMPLE TYPE=32-bit Floating Point & BIT DEPTH=32 \\
\hline & SAMPLE TYPE=32-bit Floating Point \\
\hline \multicolumn{2}{|c|}{ ALOS POLSAR DEM } \\
\hline FILENAME $=$ ALOS POLSAR DEM & PIXEL WIDTH=23.022 meters \\
\hline PROJ_DESC=UTM Zone 42/WGS84/meters & PIXEL HEIGHT $=30.844$ meters \\
\hline 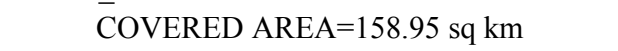 & MIN ELEVATION=977.5 m \\
\hline LOAD TIME $=0.02 \mathrm{~s}$ & MAX ELEVATION=1184.9 m \\
\hline NUM COLUMNS=524 & ELEVATION UNITS=METERS \\
\hline NUM ROWS=429 & BIT DEPTH $=32$ \\
\hline NUM BANDS=1 & SAMPLE TYPE=32-bit Floating Point \\
\hline
\end{tabular}

\section{Results and Discussion}

First, vertical differences between SRTM, ASTER GDEM, and ALOS PALSAR products were computed as the root mean squared error (RMSE) compared to GPS data. The RMSE we calculate is the most easily interpreted statistic as the square root of the mean square error because it has the same units as the quantity drawn on the vertical axis[10], [47]-[51], [18], [39].

$$
R M S E=\sqrt{\sum_{i=1}^{n} \frac{\left(y^{\prime}-y\right)^{2}}{n}}
$$

Results show that SRTM based measurements of ground control points (GCPs) exhibit RMSE of $15.72 \mathrm{~m}$ while ASTER DEM based measurements exhibits and RMSE of 18.47 $\mathrm{m}$, ALOS PALSAR exhibit RMSE of $14.02 \mathrm{~m}$ for the Water reservoir located in the plain 'figure 3'. There are AOS PALSAR outperforms SRTM and ASTER DEM in detecting vertical accuracy. 


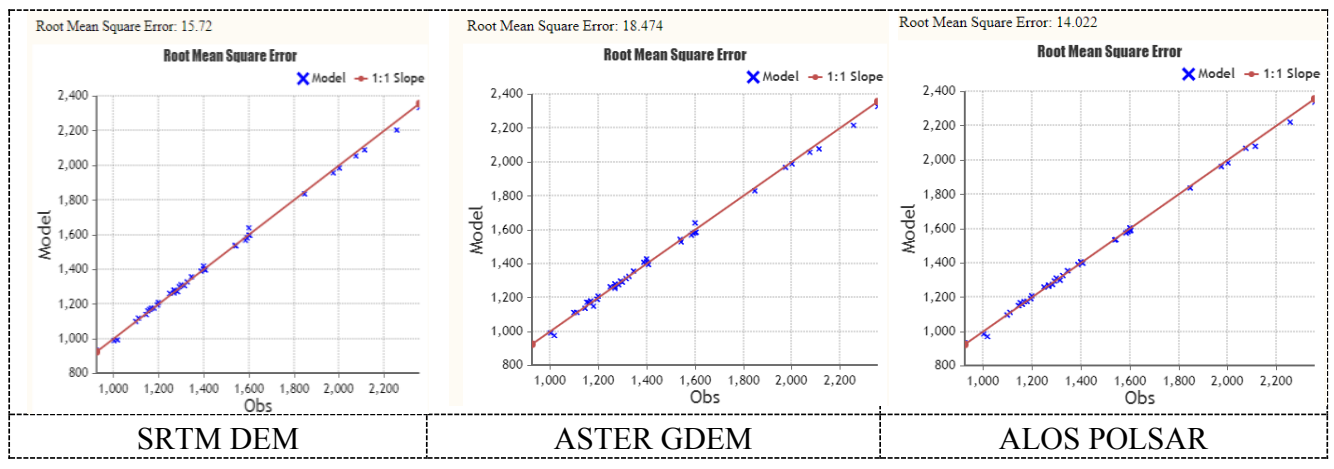

Fig. 3. RMSE results

Second, determine the storage volume and area of the reservoir using the Global Mapper program and each DEM data for comparing the DEMs[50]-[52]. The water level in the projected reservoir is approximately $1166.5 \mathrm{~m}$ relative to the sea level. We generated contours for $1170 \mathrm{~m}$ relative to the sea level using Generate Contours command. And the surface area is generated from this contour and the dam location section using Create New Area Features command from the Selected Lines option. The storage volume and area are determined on the resulting surface using the Measure Volume (Cut-and-Fill) command. The results showed three different outcomes in the three DEMs. The results are presented in 'table 1' and 'figure 3'

Table 2. The determined storage volume and area for each DEM dates

\begin{tabular}{|c|c|c|c|c|c|c|}
\hline $\begin{array}{c}\text { BASE } \\
\text { HEIGHT, } \\
\mathrm{m} \\
\left(\begin{array}{c}\text { Sea } \\
\text { Level })\end{array}\right.\end{array}$ & $\begin{array}{c}\text { FILL } \\
\text { VOLUME, } \\
\mathrm{m}^{3}\end{array}$ & $\begin{array}{c}\text { FILL } \\
\text { AREA } \\
\mathrm{sq}, \mathrm{km}\end{array}$ & $\begin{array}{c}\text { FILL } \\
\text { VOLUME, } \\
\mathrm{m}^{3}\end{array}$ & $\begin{array}{c}\text { FILL } \\
\text { AREA } \\
\text { sq, } \mathrm{km}\end{array}$ & $\begin{array}{c}\text { FILL } \\
\text { VOLUME, } \\
\mathrm{m}^{3}\end{array}$ & $\begin{array}{c}\text { FILL } \\
\text { AREA } \\
\text { sq, } \mathrm{km}\end{array}$ \\
\hline 1000 & 199286.7 & 0.0451 & 150741.62 & 0.0215 & 664082.86 & 0.1058 \\
\hline 1010 & 1064510.1 & 0.1411 & 872876.63 & 0.1305 & 2224332.4 & 0.2072 \\
\hline 1020 & 3078364.4 & 0.261 & 2788219.2 & 0.249 & 4777633.1 & 0.3218 \\
\hline 1030 & 6421532.8 & 0.429 & 5872156 & 0.3694 & 8974555.8 & 0.524 \\
\hline 1040 & 11899239 & 0.662 & 10627231 & 0.612 & 15192802 & 0.723 \\
\hline 1050 & 19794559 & 0.923 & 18153325 & 0.892 & 23753540 & 0.995 \\
\hline 1060 & 30340059 & 1.191 & 28281590 & 1.132 & 35292828 & 1.327 \\
\hline 1070 & 43831664 & 1.53 & 41027870 & 1.425 & 50279019 & 1.67 \\
\hline 1080 & 60897129 & 1.899 & 56992084 & 1.785 & 68969691 & 2.076 \\
\hline 1090 & 82349377 & 2.392 & 76967966 & 2.231 & 91905550 & 2.536 \\
\hline 1100 & 108914226 & 2.932 & 101803039 & 2.752 & 119800728 & 3.05 \\
\hline 1110 & 140977315 & 3.485 & 132096316 & 3.301 & 153043997 & 3.59 \\
\hline 1120 & 178544887 & 4.064 & 168124416 & 3.941 & 192015296 & 4.214 \\
\hline 1130 & 222763810 & 4.802 & 211437989 & 4.724 & 238214673 & 5.039 \\
\hline 1140 & 275171193 & 5.673 & 262507235 & 5.494 & 292702295 & 5.847 \\
\hline 1150 & 335891077 & 6.494 & 321822498 & 6.373 & 355296954 & 6.708 \\
\hline 1160 & 405844153 & 7.529 & 390608997 & 7.389 & 427242085 & 7.695 \\
\hline 1166,5 & 457140013 & 8.258 & 440530965 & 7.951 & 479368568 & 8.31 \\
\hline
\end{tabular}




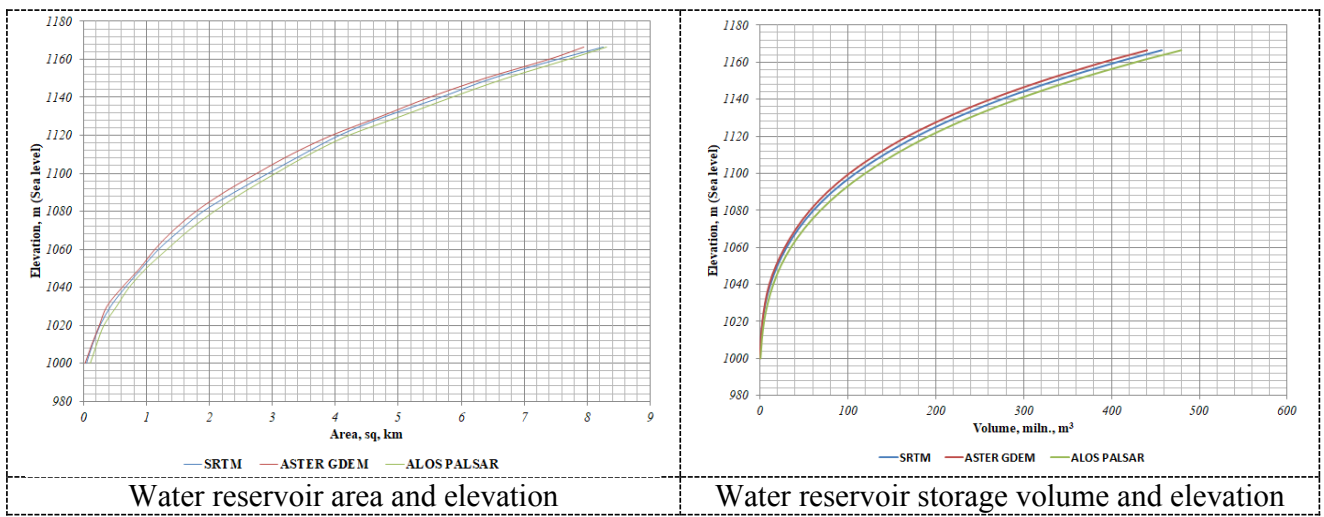

Fig. 4. Graphics of $F=f(h)$ and $W=f(h)$

Third, based on the capabilities of the Global Mapper program, we can build the longitudinal profile of the approximate location where the dam can be built[53]. And we do this in each DEM and compare 'figure 5 '. The results obtained show that the dam height is $187 \mathrm{~m}$ at ALOS PALSAR DEM, $168 \mathrm{~m}$ at ASTER GDEM, and $175 \mathrm{~m}$ at SRTM.

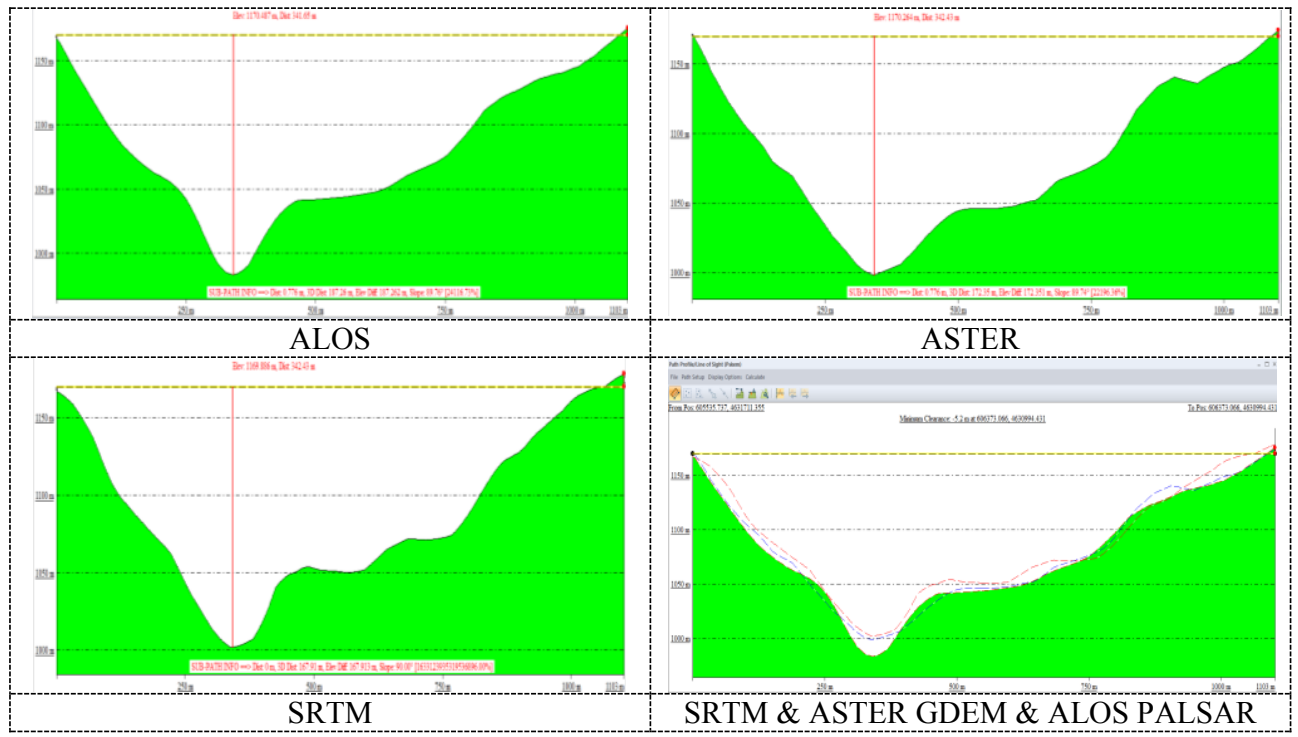

Fig. 5. The longitudinal profiles of both dam

\section{Conclusions}

The study found that using ALOS PALSAR data in the design of the proposed Pskom Reservoir for construction leads to a more accurate result. Comparing the DEM data shows that there is more difference between the vertical accuracy; the horizontal accuracy level is almost the same. The results obtained using ALOS PALSAR data determine the storage volume $\left(\mathrm{W}=479368568 \mathrm{~m}^{3}\right)$ and area $(\mathrm{F}=8,31 \mathrm{sq} ., \mathrm{km})$ of the proposed Pskom Reservoir are shown in Figure 6. 


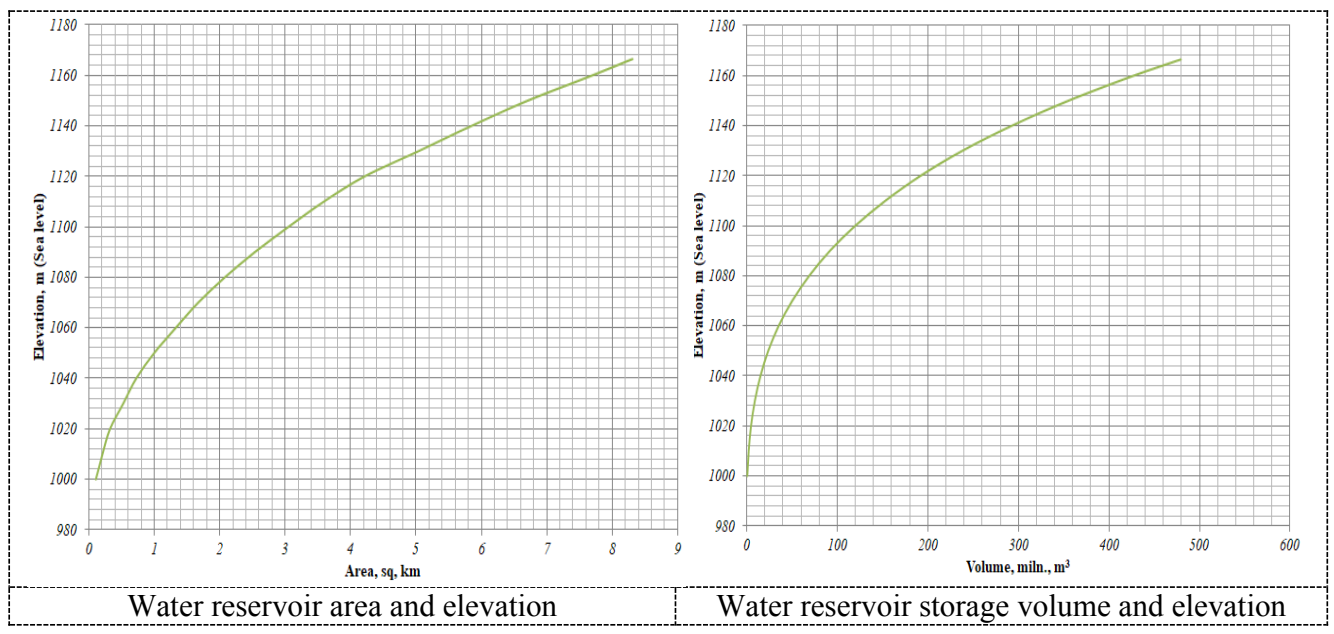

Fig. 4. Graphics of $\mathrm{F}=\mathrm{f}(\mathrm{h})$ and $\mathrm{W}=\mathrm{f}(\mathrm{h})$

\section{References}

1. R. Carley, J., Pasternack, G., Wyrick, J., and Barker, J. Significant decadal channel change 58-67years post-dam accounting for uncertainty in topographic change detection between et al., "The impact of hydropower plant on downstream river reach," Environ. Res. Eng., (2012).

2. I. G. Baird et al., "The Downstream Impacts of Hydropower Dams and Indigenous and Local Knowledge: Examples from the Peace-Athabasca, Mekong, and Amazon," Environ. Manage., vol. 67, no. 4, pp. 682-696, 2021, doi: 10.1007/s00267-02001418-x.

3. B. Rolland et al., "Hepatitis $\mathrm{C}$ in a psychiatric setting: A forgotten reservoir? | Hépatite C en milieu psychiatrique : un réservoir oublié ?," Encephale, vol. 47, no. 2, pp. 181-184, 2021, doi: 10.1016/j.encep.(2020).03.003.

4. S. Rakhmatullaev, F. Huneau, M. Bakiev, M. Motelica-Heino, and P. Le Coustumer, "Sedimentation of reservoirs in Uzbekistan: A case study of the Akdarya reservoir, Zerafshan River Basin," IAHS-AISH Publ., vol. 349, pp. 171-181, (2011)

5. S. Rakhmatullaev, F. Huneau, H. Celle-Jeanton, P. Le Coustumer, M. Motelica-Heino, and M. Bakiev, "Water reservoirs, irrigation and sedimentation in Central Asia: A first-cut assessment for Uzbekistan," Environ. Earth Sci., vol. 68, no. 4, pp. 985-998, 2013, doi: 10.1007/s12665-012-1802-0.

6. S. Rakhmatullaev, F. Huneau, H. Celle-Jeanton, P. Le Coustumer, M. Motelica-Heino, and M. Bakiev, "Water reservoirs, irrigation and sedimentation in Central Asia: A first-cut assessment for Uzbekistan," Environ. Earth Sci., vol. 68, no. 4, pp. 985-998, 2013, doi: 10.1007/s12665-012-1802-0.

7. I. S. Ramroop and D. Ph, "GIS Applications in Water Resources and Environmental Engineering," vol. 423, 2012.

8. S. Wang et al., "DEM generation from Worldview-2 stereo imagery and vertical accuracy assessment for its application in active tectonics," Geomorphology, 2019, doi: 10.1016/j.geomorph.(2019).03.016.

9. Y. Jianzhong, H. Fenqin, and L. Zhibing, "Researching the Relationships between the Environmental Change of Vegetation and the Activity of Debris Flows Based on Remote Sensing and GIS," Procedia Environ. Sci., vol. 11, pp. 918-924, 2011, doi: https://doi.org/10.1016/j.proenv.(2011).12.141. 
10. Y. Jianzhong, H. Fenqin, and L. Zhibing, "Researching the Relationships between the Environmental Change of Vegetation and the Activity of Debris Flows Based on Remote Sensing and GIS," Procedia Environ. Sci., vol. 11, pp. 918-924, 2011, doi: https://doi.org/10.1016/j.proenv.(2011).12.141.

11. M. K. Jha, A. Chowdhury, V. M. Chowdary, and S. Peiffer, "Groundwater management and development by integrated remote sensing and geographic information systems: prospects and constraints," Water Resour. Manag., vol. 21, no. 2, pp. 427-467, 2007, doi: 10.1007/s11269-006-9024-4.

12. M. N. Gebeyehu, "Remote Sensing and GIS Application in Agriculture and Natural Resource Management," Int. J. Environ. Sci. Nat. Resour., vol. 19, no. 2, 2019, doi: 10.19080/ijesnr.2019.19.556009.

13. K. Khasanov and Bakiev Masharif, "Water Reservoir Area and Volume Determination using Geoinformation Technologies and Remote Sensing," Int. J. Recent Technol. Eng., vol. 8, no. 4, pp. 5458-5461, Nov. 2019, doi: 10.35940/ijrte.d8089.118419.

14. K. S. Rawat, S. K. Singh, M. I. Singh, and B. L. Garg, "Comparative evaluation of vertical accuracy of elevated points with ground control points from ASTERDEM and SRTMDEM with respect to CARTOSAT-1DEM," Remote Sens. Appl. Soc. Environ., 2019, doi: 10.1016/j.rsase.(2018).11.005.

15. G. Amatulli, D. Mcinerney, T. Sethi, P. Strobl, and S. Domisch, "Geomorpho90m, empirical evaluation and accuracy assessment of global high-resolution geomorphometric layers," doi: 10.1038/s41597-020-0479-6.

16. N. Al-Mutairi, M. Alsahli, M. Ibrahim, R. Abou Samra, and M. El-Gammal, "Spatial Enhancement of DEM Using Interpolation Methods: A Case Study of Kuwait's Coastal Zones," Am. J. Remote Sens., vol. 7, no. 1, p. 5, 2019, doi: 10.11648/j.ajrs.20190701.12.

17. D. R. Cowan and G. R. J. Cooper, "Shuttle Radar Topography Mission," in 67th European Association of Geoscientists and Engineers, EAGE Conference and Exhibition, incorporating SPE EUROPE2005 - Extended Abstracts, 2005, doi: 10.1071/EG05334.

18. R. Bamler, "The SRTM mission: A worldwide 30m resolution DEM from SAR interferometry in 11 days," Photogramm. Week, (1999)

19. D. Cowan and G. Cooper, "The Shuttle Radar Topography Mission?a new source of near-global digital elevation data," Explor. Geophys., 2005, doi: 10.1071/EG05334.

20. R. Bhambri et al., "(No Title)," 2017, doi: 10.1038/s41598-020-61277-8.

21. T. G. Farr et al., "The shuttle radar topography mission," Rev. Geophys., 2007, doi: 10.1029/2005RG000183.

22. A. Patel, S. K. Katiyar, and V. Prasad, "Performances evaluation of different open source DEM using Differential Global Positioning System (DGPS)," Egypt. J. Remote Sens. Sp. Sci., 2016, doi: 10.1016/j.ejrs.2015.12.004.

23. A. Sharma and K. N. Tiwari, "A comparative appraisal of hydrological behavior of SRTM DEM at catchment level," J. Hydrol., 2014, doi: 10.1016/j.jhydrol.2014.08.062.

24. T. Tachikawa et al., "ASTER global digital elevation model version 2 - summary of validation results," Arch. Cent. Jt. Japan-US ASTER Sci. Team, (2011)

25. A. Mondal, D. Khare, S. Kundu, S. Mukherjee, A. Mukhopadhyay, and S. Mondal, "Uncertainty of soil erosion modelling using open source high resolution and aggregated DEMs," Geosci. Front., 2017, doi: 10.1016/j.gsf.(2016).03.004.

26. H. T. Pham, L. Marshall, F. Johnson, and A. Sharma, "A method for combining SRTM DEM and ASTER GDEM2 to improve topography estimation in regions without reference data," Remote Sens. Environ., 2018, doi: 
10.1016/j.rse.(2018).03.026.

27. L. G. Courty, J. C. Soriano-Monzalvo, and A. Pedrozo-Acuña, "Evaluation of openaccess global digital elevation models (AW3D30, SRTM, and ASTER) for flood modelling purposes," J. Flood Risk Manag., vol. 12, no. S1, Oct. 2019, doi: $10.1111 / \mathrm{jfr} 3.12550$.

28. J. Ngula Niipele and J. Chen, "The usefulness of alos-palsar dem data for drainage extraction in semi-arid environments in The Iishana sub-basin," J. Hydrol. Reg. Stud., vol. 21, 2019, doi: 10.1016/j.ejrh.(2018).11.003.

29. A. Das, R. Agrawal, and S. Mohan, "Topographic correction of ALOS-PALSAR images using InSAR-derived DEM," Geocarto Int., vol. 30, no. 2, pp. 145-153, Feb. 2015, doi: 10.1080/10106049.2014.883436.

30. T. Borner et al., "ALOS PALSAR products verification," Int. Geosci. Remote Sens. Symp., no. May 2014, pp. 5214-5217, 2007, doi: 10.1109/IGARSS.2007.4424037.

31. B. Caglar, K. Becek, C. Mekik, and M. Ozendi, "On the vertical accuracy of the ALOS world 3D-30m digital elevation model," Remote Sens. Lett., vol. 9, no. 6, 2018, doi: 10.1080/2150704X.2018.1453174.

32. J. R. Santillan, M. Makinano-Santillan, and R. M. Makinano, "Vertical accuracy assessment of ALOS World 3D - 30M Digital Elevation Model over northeastern Mindanao, Philippines," in International Geoscience and Remote Sensing Symposium (IGARSS), 2016, vol. 2016-Novem, doi: 10.1109/IGARSS.2016.7730400.

33. J. A. E. A. JAXA, "ALOS Data Users Handbook," Earth Obs. Res. Appl. Cent. Japan Aerosp. Explor. Agency, no. March, p. 158, (2008)

34. C. Chen, X. Wang, C. Yan, B. Guo, and G. Liu, "A total error-based multiquadric method for surface modeling of digital elevation models," GIScience Remote Sens., 2016, doi: 10.1080/15481603.2016.1172396.

35. K. Khasanov, "Evaluation of ASTER DEM and SRTM DEM data for determining the area and volume of the water reservoir," IOP Conf. Ser. Mater. Sci. Eng., vol. 883, no. $1,(2020)$

36. X. Liu, Z. Zhang, J. Peterson, and S. Chandra, "The effect of LiDAR data density on DEM accuracy," MODSIM 2007 - Int. Congr. Model. Simul. - Land, Water Environ. Manag. Integr. Syst. Sustain. Proc., pp. 1363-1369, (2007)

37. I. Elkhrachy, "Vertical accuracy assessment for SRTM and ASTER Digital Elevation Models: A case study of Najran city, Saudi Arabia," Ain Shams Eng. J., 2018, doi: 10.1016/j.asej.(2017).01.007.

38. L. G. Courty, J. C. Soriano-Monzalvo, and A. Pedrozo-Acuña, "Evaluation of openaccess global digital elevation models (AW3D30, SRTM, and ASTER) for flood modelling purposes," J. Flood Risk Manag., vol. 12, no. S1, 2019, doi: $10.1111 / \mathrm{jfr} 3.12550$.

39. M. del R. González-Moradas and W. Viveen, "Evaluation of ASTER GDEM2, SRTMv3.0, ALOS AW3D30 and TanDEM-X DEMs for the Peruvian Andes against highly accurate GNSS ground control points and geomorphological-hydrological metrics," Remote Sens. Environ., 2020, doi: 10.1016/j.rse.2019.111509.

40. D. F. Maune, "Digital Elevation Model ( DEM ) Whitepaper NRCS High Resolution Elevation Data," p. 120, (2010)

41. G. Schumann, P. Matgen, M. E. J. Cutler, A. Black, L. Hoffmann, and L. Pfister, "Comparison of remotely sensed water stages from LiDAR, topographic contours and SRTM," ISPRS J. Photogramm. Remote Sens., 2008, doi: 10.1016/j.isprsjprs. (2007).09.004.

42. N. Chrysoulakis, M. Abrams, Y. Kamarianakis, and M. Stanislawski, "Validation of ASTER GDEM for the area of Greece," Photogramm. Eng. Remote Sensing, 2011, doi: 10.14358/pers.77.2.157. 
43. T. Chu and K. E. Lindenschmidt, "Comparison and Validation of Digital Elevation Models Derived from InSAR for a Flat Inland Delta in the High Latitudes of Northern Canada," Can. J. Remote Sens., vol. 43, no. 2, 2017, doi: 10.1080/07038992.2017.1286936.

44. K. G. Nikolakopoulos, E. K. Kamaratakis, and N. Chrysoulakis, "SRTM vs ASTER elevation products. Comparison for two regions in Crete, Greece," Int. J. Remote Sens., vol. 27, no. 21, pp. 4819-4838, Nov. 2006, doi: 10.1080/01431160600835853.

45. M. Mukul, V. Srivastava, S. Jade, and M. Mukul, "Uncertainties in the Shuttle Radar Topography Mission (SRTM) Heights: Insights from the Indian Himalaya and Peninsula," Sci. Rep., vol. 7, Feb. 2017, doi: 10.1038/srep41672.

46. K. Khasanov, "Evaluation of ASTER DEM and SRTM DEM data for determining the area and volume of the water reservoir," IOP Conf. Ser. Mater. Sci. Eng., vol. 883, Jul. 2020, doi: 10.1088/1757-899X/883/1/012063.

47. L. Hawker, J. Neal, and P. Bates, "Accuracy assessment of the TanDEM-X 90 Digital Elevation Model for selected floodplain sites," Remote Sens. Environ., 2019, doi: 10.1016/j.rse.2019.111319.

48. V. Vanthof and R. Kelly, "Water storage estimation in ungauged small reservoirs with the TanDEM-X DEM and multi-source satellite observations," Remote Sens. Environ., 2019, doi: 10.1016/j.rse.2019.111437.

49. Y. Su and Q. Guo, "A practical method for SRTM DEM correction over vegetated mountain areas," ISPRS J. Photogramm. Remote Sens., 2014, doi: 10.1016/j.isprsjprs. (2013)

50. K. Khasanov, РУКОВОДСТВО по определению площуади и объема водохранилища с использованием геоинформачионных технологий $u$ дистанционного зондирования. (2020)

51. M. Bakiev and K. Khasanov, "Comparison of digital elevation models for determining the area and volume of the water reservoir," Int. J. Geoinformatics, vol. 17, no. 1, pp. $37-45,(2021)$

52. K. Khasanov, "Water Reservoir Area and Volume Determination using Geoinformation Technologies and Remote Sensing," Int. J. Recent Technol. Eng., 2019, doi: 10.35940/ijrte.d8089.118419.

53. K. Khasanov, "Guidelines for Determining the Area and Volume of A Water Reservoir Using Geographic Information Technologies and Remote Sensing," p. 32, (2020) 